\title{
ANXIETY AND ASSOCIATED FACTORS IN WOMEN WITH A LOW-GRADE ABNORMAL CERVICAL SMEAR TEST: A PROSPECTIVE STUDY
}

\author{
Serkan KARADAG ${ }^{1}$, B. Pinar Cilesiz GOKSEDEF ${ }^{1}$, Ahmet CETIN ${ }^{1}$, Mustafa YENIGUN ${ }^{2}$ \\ ${ }^{1}$ Haseki Teaching and Research Hospital; Obstetrics and Gynecology, Istanbul, Turkey \\ 2 Haseki Teaching and Research Hospital, Department of Internal Medicine, Istanbul, Turkey
}

\begin{abstract}
SUMMARY
Objective: The aims of the study were to quantify the levels of anxiety associated with having received a low-grade abnormal smear result, identify factors associated with increased levels of anxiety.

Material and methods: One hundred consecutive women referred for colposcopy for ASC-US result. Women in the study group completed prior to colposcopy the Hospital Anxiety and Depression Scale (HADS) which is a self-report inventory that consists of 14 items on two subscales. Socio-demographic and lifestyle factors associated with the psychosocial impact of the abnormal smear result were also assessed.

Results: Having had children was a significant predictor of high anxiety scoring. Anxiety was significantly higher in women with low educational level. Women were educated 1-8 years were significantly more likely anxious. Conclusion: Interventions focus particularly on women's knowledge and understanding of smear results to reduce the adverse psychosocial impact of receiving an ASC-US cervical smear result.
\end{abstract}

Key words: anxiety, ASC-US, cervical smear, depression, HADS

Journal of Turkish Society of Obstetrics and Gynecology, (J Turk Soc Obstet Gynecol), 2012; Vol: 9, Issue: 3, Pages: 164- 9

\section{LOW GRADE SMEAR SONUCU OLAN KADINLARDA ANKSIYYTE VE ILIŞKILI FAKTÖRLER: PROSPEKTIF ÇALIŞMA}

\section{ÖZET}

Amaç: Low-grade anormal smear sonucu alan kadınlarda anksiyete düzeyini ölçmek ve artmış anksiyete ile ilişkili olabilecek faktörleri belirlemektir.

Giriş ve yöntemler: ASC-US smear sonucuna sahip, kolposkopi yapılmak üzere yönlendirilmiş, ardışık 100 kadın çalışmaya alındl. Kolposkopi öncesinde 14 soruluk iki alt değerlendirmesi olan Hastane Anksiyete ve Depresyon Skalası (HADS) dolduran olgular aynı zamanda anormal smear sonucu sonrası oluşabilecek psikososyal değişiklikler ile ilişsili olabilecek sosyo-demografik ve hayat tarzı faktörleri açısından değerlendirildi.

Bulgular: Çocuk sahibi olmak yüksek anksiyete skorları için prediktör olarak belirlendi. Anksiyete düşük eğitim düzeyine sahip kadınlarda anlamlı olarak yüksek saptandı. Bir ile 8 yıl arasında ĕgitim almış kadınlar daha fazla anksiyeteye sahip olarak saptandl.

Sonuç: ASC-US sonucuna sahip olgularda, bu nedenle oluşabilecek anksiyeteyi azaltmak için, smear sonucu konusunda olguların bilgilendirilmesine ve sonucun anlaşılır hale getirilmesine çalışılmalıdır.

Anahtar kelimeler: anksiyete, ASC-US, depresyon, HADS, servikal smear

Türk Jinekoloji ve Obstetrik Derneği Dergisi, (J Turk Soc Obstet Gynecol), 2012; Cilt: 9, Sayl: 3, Sayfa: 164- 9

Address for Correspondence: Dr. B. Pınar Çilesiz Göksedef. Haseki Eğitim ve Araştırma Hastanesi, Kadın Doğum Kliniği, 34393 Aksaray, İstanbul Phone: + 90 (532) 4935123

e-mail: bpgoksedef@yahoo.com

Received: 09 November 2011, revised: 07 April 2012, accepted: 18 April 2012, online publication: 24 April 2012 


\section{INTRODUCTION}

The abnormal cervical cytological prevalence rate in Turkey is lower than in Europe and North America. This might be due to sociocultural differences, lack of population-based screening programs, or a lower HPV prevalence rate in Turkey. Overall, the prevalence of cervical cytological abnormalities was $1.8 \%$; the prevalence of ASCUS was $1.07 \%(1)$. Cervical cytological screen aims to identify abnormal cells on the cervix at an early asymptomatic stage and thus, through initiating interventions, prevent the development of invasive cervical cancer. For women, receipt of an abnormal smear test result frequently leads to heightened levels of anxiety(2-4). Women who have received an abnormal smear result have reported frequent worries and feeling worse about their body (5). Previous studies have also shown that women referred for colposcopy after an abnormal cervical smear often exhibit an increase in anxiety and stress. Women with an abnormal smear result has a fear about cancer and concerns about infertility and worry for the gynecological examination and colposcopy $(6,7)$. It is important to know which women are at the greatest risk of experiencing severe anxiety in conjunction with an abnormal cervical smear and referral for colposcopy. Description of factors associated with higher levels of anxiety could be helpful for identifying particularly vulnerable subgroups of the population and targets that could be addressed in interventions aimed at helping alleviate anxiety.

The aims of the study were to quantify the levels of anxiety and depression associated with having received a low-grade abnormal smear result, identify factors associated with increased levels of anxiety.

\section{MATERIALS AND METHODS}

A total of one hundred and seven participants were consecutively asked to participate in a study after being informed of an atypical squamous cell undetermined significance (ASC-US) from February 2010 and January 2011. Seven of them declined to participate in the study. The inclusion criteria were non pregnant women aged 21-59, first time referral for colposcopy, mentally healthy and speaking and reading Turkish fluently. Participants were excluded if they were pregnant, or had previous abnormal cytology, destructive or excision treatment for proven or suspected cervical lesions.

After giving their informed consent the women were asked to fill in the forms of the Hospital Anxiety and Depression Scale (HADS). The women were given privacy to complete their forms in the examination room and were encouraged to ask questions if necessary. The examiner (S.K) waited in a room nearby and could be reached at any time. After the forms were completed, an interview (by S.K) was conducted regarding the woman's socio-demographic and lifestyle questionnaire. The socio-demographic and lifestyle questionnaire collected information including marital status, education, since leaving school, employment status, pregnancy and childbirth, smoking habits and physical activity.

The HADS is a well-validated instrument used to screen for clinically significant depression and anxiety. It is a self-report inventory that consists of 14 items on two subscales, seven items measuring anxiety and seven measuring depression. Each item is scored on a four-point scale from 0 to 3 . The items are summed yielding two subscale scores each ranging from 0 to 21. Scores were categorized to indicate 'non-cases' (scores 0-7), 'possible cases' (scores 8-10) and 'probable cases' (scores of 11 or more) ${ }^{(8)}$. The reliability and validity of the Turkish version of HADS was tested by Aydemir ${ }^{(9)}$.

Statistical analyses were carried out using the Statistical Package for the Social Sciences, version 15.0 (SPSS, Chicago, IL, USA). Student's t test was used for comparisons for normally distributed variables, and the Mann-Whitney U test was used for categorical variables. Factors associated with anxiety were investigated using multiple logistic regressions to compute odds ratios (OR). The binary outcome variable analysis were done using score of $>10$ to identify 'cases' with those scoring 10 or less classified as 'noncases'.

\section{RESULTS}

The mean age of participants was $37.7 \pm 8.7$ and most of the women (39\%) were in the 40-49 year age group (Table I). The vast majority of women were married (88\%), non-employee (82\%) and premenopausal (86\%). The most of the women reported that they had never 
smoked (64\%), 27\% that they were current smoker and $9 \%$ that they were ex-smokers.

Table I: Socio-demographic characteristics of respondents participating in the baseline psychological assessment.

\begin{tabular}{|c|c|c|}
\hline & $\mathbf{n}$ & $\%$ \\
\hline \multicolumn{3}{|l|}{ Age group } \\
\hline 20-29 years & 20 & 20 \\
\hline $30-39$ years & 34 & 34 \\
\hline $40-49$ years & 39 & 39 \\
\hline $50-59$ years & 7 & 7 \\
\hline Gravida (median, range) & \multicolumn{2}{|c|}{$3(0-11)$} \\
\hline Parity (median, range) & \multicolumn{2}{|c|}{$2(0-8)$} \\
\hline \multicolumn{3}{|l|}{ Marital status } \\
\hline Married & 88 & 88 \\
\hline Single & 5 & 5 \\
\hline Divorced/widowed & 7 & 7 \\
\hline \multicolumn{3}{|l|}{ Employment Status } \\
\hline Employee & 18 & 18 \\
\hline Non-Employee & 82 & 82 \\
\hline \multicolumn{3}{|l|}{ Educational Status } \\
\hline $1-8$ years & 83 & 83 \\
\hline $9-12$ years & 10 & 10 \\
\hline$>12$ years & 7 & 7 \\
\hline \multicolumn{3}{|l|}{ Smoking Status } \\
\hline Current smoker & 27 & 27 \\
\hline Never Smoker & 64 & 64 \\
\hline \multicolumn{3}{|l|}{ Menopause Status } \\
\hline Menopausal & 14 & 14 \\
\hline Premenapozal & 86 & 86 \\
\hline \multicolumn{3}{|l|}{ Contraceptive Method } \\
\hline Nothing & 59 & 59 \\
\hline Condom & 18 & 18 \\
\hline Introuterine device & 14 & 14 \\
\hline The pill & 7 & 7 \\
\hline Ligation of tubes & 1 & 1 \\
\hline Hormonal implant & 1 & 1 \\
\hline
\end{tabular}

The means of the scores of HADS anxiety and depression were $11.4 \pm 4.8$ and $9.2 \pm 4.3$. Over half of the women $(59 \%)$ had scores that indicated a probable clinically significant level of anxiety (scored $>10$ on the HADS anxiety subscale), $21 \%$ of the women were classed as being a non-case (scored $<8$ ), $20 \%$ of the cases had scores consistent with being possible cases (scored 8-10). Almost half of the women (43\%) had scores that indicated a probable clinically significant level of depression (scored $>10$ on the HADS depression subscale), $31 \%$ of the women were classed as being a non-case (scored $<8$ ), $26 \%$ of the cases had scores consistent with being possible cases (scored 8-10). In univariate analysis, statistically significant associations were found between anxiety and ever having had a child, and educational level (Table II). This was accounted for by an increased proportion scoring $>10$ among those having had children $(\mathrm{p}=0.03)$. A higher proportion of women who had 1-8 years education scored 8-10 or $>10$ on the HADS anxiety subscale than women in other education level groups $(p<0.0001)$. The associations between anxiety and ever having had a child and educational level remained in the multivariate analysis. Women who had had children were significantly more likely to be anxious than women who never had children (OR: 2.07, 95\% CI: 1.8-17.3) $(\mathrm{p}=0.04)$. When those scoring $>10$ on the HADS anxiety subscale were combined, the multivariate OR for the women who had $>12$ years education vs 1-8 years groups was statistically significantly less than unity ( OR: $0.5795 \% \mathrm{CI}$ : 0.100.76) $(\mathrm{p}=0.007)$.

In univariate analysis, statistically significant associations were found between HAD depression scores and ever having had a child, employment status and educational level $(\mathrm{p}=0.03, \mathrm{p}=0.04$ and $\mathrm{p}=0.03$; respectively) (Table III). The associations between depression and ever having had a child remained in the multivariate analysis. Women who had had children were significantly more likely to have $>10$ HAD depression score (OR: 3.29 \%95 CI: 1.68-15.93).

\section{DISCUSSION}

We found that $59 \%$ of women who had recently received an ASC-US smear test result scored $\geq 11$ on the anxiety subscale of the HADS, and a further $20 \%$ scored between 8 and 10 . The frequency scoring $\geq 11$ was substantially higher than that observed in nonclinical postmenopausal Turkish women $(13.7 \%)^{(10)}$. Moreover our findings are higher than those from previous studies of women who had had higher grade abnormal smear results ${ }^{(11,12)}$. Recently, TOMBOLA (Trial of Management of Borderline and Other Lowgrade Abnormal smears) group form UK published the results of anxiety over 3500 of women with low grade cervical cytology ${ }^{(12)}$. They reported that $23 \%$ of women who scored $\geq 11$ on the anxiety subscale of the HADS, and a further $20 \%$ scored between 8 and 10. Our results indicated higher percentage of women who scored of anxiety $\geq 11$ on the anxiety subscale of 
Table II: Associations between the HADS anxiety subscale and socio-demographic factors.

\begin{tabular}{|c|c|c|c|c|c|c|c|}
\hline & \multicolumn{4}{|c|}{ Univariate Analysis } & \multicolumn{3}{|c|}{ Multivariate Analysis } \\
\hline & $\begin{array}{l}<8 \\
\text { (n) }\end{array}$ & $\begin{array}{c}8-10 \\
\text { (n) }\end{array}$ & $\begin{array}{r}>10 \\
\text { (n) }\end{array}$ & $\mathbf{p}$ & OR & $\% 95$ CI & $\mathbf{p}$ \\
\hline \multicolumn{8}{|l|}{ Age Groups } \\
\hline $20-29$ & 7 & 4 & 9 & 0.27 & & & \\
\hline $30-39$ & 5 & 9 & 20 & & & & \\
\hline $40-49$ & 6 & 6 & 27 & & & & \\
\hline $50-59$ & 2 & 1 & 3 & & & & \\
\hline$>60$ & 1 & 0 & 0 & & & & \\
\hline \multicolumn{8}{|l|}{ Having Children } \\
\hline No & 6 & 3 & 4 & 0.03 & 1 & & \\
\hline Yes & 15 & 17 & 55 & & 2.07 & $(1.8-17.3)$ & 0.04 \\
\hline \multicolumn{8}{|l|}{ Marital status } \\
\hline Married & 17 & 19 & 52 & 0.11 & & & \\
\hline Single & 3 & 1 & 1 & & & & \\
\hline Divorced & 1 & 0 & 6 & & & & \\
\hline \multicolumn{8}{|l|}{ Educational status } \\
\hline $1-8$ years & 10 & 16 & 48 & 0.000 & 1 & & \\
\hline $9-12$ years & 7 & 1 & 2 & & 3.24 & $(0.35-29.51)$ & 0.29 \\
\hline$>12$ years & 4 & 0 & 3 & & 0.57 & $(0.10-3.06)$ & 0.51 \\
\hline \multicolumn{8}{|l|}{ Employment status } \\
\hline Employee & 4 & 3 & 11 & 0.92 & & & \\
\hline Non-employee & 17 & 17 & 48 & & & & \\
\hline \multicolumn{8}{|l|}{ Smoking status } \\
\hline Never smoked & 12 & 17 & 35 & 0.13 & & & \\
\hline Smokers & 8 & 1 & 18 & & & & \\
\hline Ex-smokers & 1 & 2 & 6 & & & & \\
\hline \multicolumn{8}{|l|}{ Menopausal status } \\
\hline Menopause & 2 & 2 & 10 & 0.59 & & & \\
\hline Premenopause & 19 & 18 & 49 & & & & \\
\hline
\end{tabular}

Table III: Associations between the HADS depression subscale and socio-demographic factors.

\begin{tabular}{|c|c|c|c|c|c|c|c|}
\hline & \multicolumn{4}{|c|}{ Univariate Analysis } & \multicolumn{3}{|c|}{ Multivariate Analysis } \\
\hline & $\begin{array}{l}<8 \\
\text { (n) }\end{array}$ & $\begin{array}{c}8-10 \\
\text { (n) }\end{array}$ & $\begin{array}{r}>10 \\
\text { (n) }\end{array}$ & $\mathbf{p}$ & OR & \%95 CI & $\mathbf{p}$ \\
\hline \multicolumn{8}{|l|}{ Age Groups } \\
\hline 20-29 & 8 & 5 & 7 & 0.19 & & & \\
\hline $30-39$ & 9 & 12 & 13 & & & & \\
\hline $40-49$ & 9 & 8 & 22 & & & & \\
\hline $50-59$ & 4 & 1 & 1 & & & & \\
\hline$>60$ & 1 & 0 & 0 & & & & \\
\hline \multicolumn{8}{|l|}{ Having Children } \\
\hline No & 8 & 2 & 3 & 0.03 & 1 & & \\
\hline Yes & 23 & 24 & 40 & & 3.29 & $1.68-15.93$ & 0.03 \\
\hline \multicolumn{8}{|l|}{ Marital status } \\
\hline Married & 27 & 25 & 36 & 0.26 & & & \\
\hline Single & 3 & 0 & 2 & & & & \\
\hline Divorced & 1 & 1 & 5 & & & & \\
\hline \multicolumn{8}{|l|}{ Educational Level } \\
\hline $1-8$ years & 21 & 24 & 38 & 0.03 & 1 & & \\
\hline $9-12$ years & 4 & 2 & 4 & & 0.20 & $0.01-2.78$ & 0.23 \\
\hline$>12$ years & 6 & 0 & 1 & & 0.26 & $0.02-2.60$ & 0.25 \\
\hline \multicolumn{8}{|l|}{ Employment status } \\
\hline Employee & 9 & 1 & 8 & 0.04 & 1 & & \\
\hline Non-employee & 22 & 25 & 35 & & 0.72 & $0.20-2.54$ & 0.61 \\
\hline \multicolumn{8}{|l|}{ Smokers } \\
\hline Never smoke & 22 & 20 & 22 & 0.06 & & & \\
\hline Smokers & 6 & 3 & 18 & & & & \\
\hline Ex-smokers & 3 & 3 & 3 & & & & \\
\hline \multicolumn{8}{|l|}{ Menopausal status } \\
\hline Menopause & 5 & 3 & 6 & 0.88 & & & \\
\hline Premenopause & 26 & 23 & 37 & & & & \\
\hline
\end{tabular}


the HADS than the TOMBOLA study. It can be explained by lower sociocultural and educational level of our population compared with TOMBOLA population. Only $7 \%$ of women had a degree from collage/university and $18 \%$ of women were employee in our cohort, $25 \%$ of TOMBOLA population had a degree from collage/university and $74 \%$ of them had full time or part time paid employment. In addition to these reason; our cohort had higher depression scores compared TOMBOLA study. The latest study was reported as the vast majority of women (91\%) were classed as non-cases on the HADS depression subscale but almost half of the women (43\%) scored that indicated a probable clinically significant level of depression in our study. Possibly; higher percent of the women in depressive mood could affect the anxiety level of the women in our population.

Having had children was a significant predictor of scoring $\geq 11$ on the HADS anxiety subscale. Previous study has shown that there were higher rates of psychiatric disorders in women with children, although the authors of the study have suggested that the difference was due to an effect of marriage rather than parity ${ }^{(15)}$. Our study showed that marital status was not associated with anxiety in our multivariate model.

In the current study, anxiety was significantly higher in lower educational level. Women were educated 18 years were significantly more likely to score $\geq 11$ on the HADS anxiety subscale. This result could be explained by women, who have knowledge about cervical screen and possible results or have previous screen, can be less anxious than the others. This is congruent with a recent study of women who had received low grade cytological abnormal results among who were not well trained were found to be a risk factor for anxiety(12).

The HADS, which have been widely used in both clinical and non-clinical settings, was used to screen anxiety and depression in this study. In terms of classifying respondents, investigators have used a variety of schemes, including cut-offs at $8^{(12,13)}$ and $11^{(14)}$. We decided to take a score of $\geq 11$ as indicating a level of anxiety that could be considered abnormal and, therefore, may warrant intervention. This categorization was chosen because the aim of interventions would be to define the optimum number of women 'cases'.

As far as we aware; this is the only study to have focused on anxiety of women with ASC-US smears and examined a population which is lack of a National Cervical Screening Programme. The methodological strength of our study is that all women were interviewed by the same examiner, in the same way. But the study limited by low number of participants and the participants were recruited from the single center.

We have found a high prevalence of anxiety among women who have an ASC-US result, and that the proportion scoring in the abnormal range compared with previous studies. We also found that women who are at highest risk of anxiety tend to have children and have poor education. Strategies are needed to minimize the adverse effects of a low-grade smear result on women. Interventions focus particularly on women's knowledge and understanding of smear results to reduce the adverse psychosocial impact of receiving an ASCUS cervical smear result.

\section{REFERENCES}

1. Ayhan A, Dursun P, Kuşçu E, Mülayim B, Haberal N, Ozen $\mathrm{O}$, et al. Prevalence of cervical cytological abnormalities in Turkey. Int J Gynaecol Obstet. 2009;106(3): 206- 9.

2. Gath DH, Hallam N, Mynors-Wallis L, Day A, Bond SAK. Emotional reactions in women attending a UK colposcopy clinic. J Epidemiol Community Health 1995; 49: 79- 83.

3. Bell S, Porter M, Kitchener H, Fraser C, Fisher P, Mann E. Psychological response to cervical screening. Prev Med 1995; 24: $610-6$.

4. Maissi E, Marteau TM, Hankins M, Moss S, Legood R, Gray A. Psychological impact of human papillomavirus testing in women with borderline or mildly dyskaryotic cervical smear test results: cross sectional questionnaire study. BMJ 2004; 328: 1293-1300.

5. Lerman C, Miller S M, Scarborough R, Hanjani P, Nolte S, Smith D. Adverse psychologic consequences of positive cytologic cervical screening. Am J Obstet Gynecol 1991; 165 : 658-62.

6. Somerset M, Peters TJ. Intervening to reduce anxiety for women with mild dyskaryosis: do we know what works and why? J Adv Nurs 1998; 28: 563- 79.

7. Kavanagh AM, Broom DH. Women's understanding of abnormal cervical smear test results: a qualitative interview study. BMJ 1997; 314: 1388-91.

8. Fayers P, Machin D. 2000. Quality of Life. Assessment, Analysis and Interpretation. Chichester: John Wiley and Sons Ltd. 
9. Aydemir Ö. The reliability and validity of the Turkish form of Hospital Anxiety and Depression Scale. Turkish J Psychiatry 1997; 8: 280- 7 .

10. Tokuç B, Kaplan P.B., Balık G.Ö, Gül H. Quality of life Among Women who were Attending to Trakya University Hospital Menopause clinic. Journal of Turkish Obstet Gynecol 2006; 3(4): 281- 7 .

11. Bell S, Porter M, Kitchener H, Fraser C, Fisher P, Mann E. Psychological response to cervical screening. Prev Med 1995; 24: 610- 6.

12. Gray NM, Sharp L, Cotton SC, Masson LF, Little J, Walker LG et al. Psychological effects of a low-grade abnormal cervical smear test result: anxiety and associated factors. British Journal of Cancer 2006; 94: 1253- 62

13. Osborne RH, Elsworth GR, Hopper JL. Age-specific norms and determinants of anxiety and depression in 731 women with breast cancer recruited through a populationbased cancer registry. Eur J Cancer 2003; 39: 755- 62.

14. Pascoe S, Edelman S, Kidman A. Prevalence of psychological distress and use of support services by cancer patients at Sydney hospitals. Aust NZ J Psychiatry 2000; 34: 785- 92.

15. Dean C, White AP. A twin study examining the effect of parity on the prevalence of psychiatric disorder. J Affect Disord 1996; 38: 145- 52 . 